要 旨：症例は初診時64歳の女性, 1980年険診にて肝機能異常を指摘され第 1 回入院. 胆道系 䣼素中心の異常と，肝組織上グ䩗の線維性拡大，炎症細胞浸潤をみたが，経静脈的胆道造影に ては総胆管像に異常なく，注腸透視にも異常をみなかった。1987年第 2 回目の入院では，胆道 系酵素が著増しており，ERCPにて肝内胆管及び総胆管の不整狭窄像がみられ，原発性硬化性 胆管炎（PSC）に合致した所見であった。また注腸透視にて右半結腸型潰瘍性大腸炎 (UC)の 所見をみた。1988年に初めて黄疸が出現し，UDCA を投与したが現在まで黄疸の消長を繰り返 し，肝性脳症の出現もみている．また ERCP 上も胆管像に著変はなかった。本例では，11年間 の経過観察中に胆管病変は肝内から肝外へ進展し, 肝内 PSC が UCの発症に先行していた。 たUDCA の投与は胆道系酵素値を改善したが, 黄疸の出見や肝病変の進展は抑制しえなかっ た.

索引用語： 原発性硬化性胆管炎潰瘍性大腸炎 ウルソデオキシュール酸 (UDCA)

はじめに

原発性硬化性胆管炎 (primary sclerosing cholangitis，PSC）は，原因不明の胆道系の炎症性硬化性病 変により閉塞性黄疸をきたし，最終的には，肝硬変， 肝不全に至る比較的まれな疾患である ${ }^{1,21}$. 近年は内視 鏡的逆行性胆管膵管造影法 (endoscopic retrograde cholangiopancratography，ERCP）経皮経肝胆道造 影法 - percutaneous transhepatic cholangiography, PTC)などの診断技術の発達により症例が集積されて おり，無症候性にて長期間経過する例も報告され ${ }^{3-51}$. 本疾患の予後に関して必ずしる不良とはいえないこと が明らかにされている。东た近年 PSCに特有とされる 肝組織所見む明らかにされてきたこともあり年, 病変 部位についても，従来多く報告されてきた胆管全域に 及ぶもの, 肝外胆管のみに病变が及ぶものに加えて, 肝内胆管のみに病变が限局する肝内型 PSC の報告例

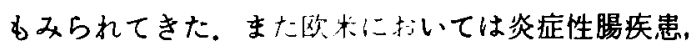
とくに潰湯性大腸炎（ulcerative colitis, UC) を合併 する頻度が高く，精力的に研究が進められている。本 邦に拉けるUCの合併頻度は低いが，少数ながら報告 例が見られている。この土うに臨床経過については,

*富山労災病院内科

*. 同病理

〈受付日1992年 8 月 5 日 $>$

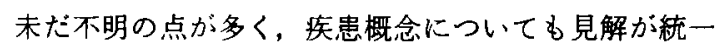
されていない，治療の面においても，近年ウルンデオ

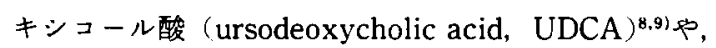
colchicine $e^{10)}$, penicillamine ${ }^{11}$ などの, 治療法が試みら られており一部の症例においての有効性が報告されて いる.

今回我々は，無症候性肝内型 PSC として発見され， 以後11年間におたって症候性への進展を観察しえた UC 合併 PSC の 1 例を経験したので，その臨床経過を 中心に，若干の考察を加之報告する。

\section{症例}

患者：初診時64歳，女性.

家族歴：特記すべきこなしし。

既往歴：特記すべきことなし，輸血歴なし，飲酒歴 なし.

現病歴：1980年, 住民挨診にて肝機能異常を指摘さ 机当科第 1 回入院. ALP $134 \mathrm{IU} / l, \gamma$-GTP $264 \mathrm{IU} / l$, GOT $45 \mathrm{U} / l$, GPT $51 \mathrm{U} / l$ と胆道系醅素中心の異常が 見られた（Table）。肝生娭（Fig. 1）ではグ鞘の線維 性拡大と, 资症細胞浸潤が見られたか，経静脈的胆道 造影（DIC）（Fig. 2)にては総胆管に異常なく(retrospective には肝内胆管型PSCが疑われる)，また便秘 の訴えがあったため施行した注腸透視では病変は認め られなかった，その後、検診を受けず放置していたが 
Table

a) Liver function test during clinical course

\begin{tabular}{|c|c|c|c|c|c|c|c|c|c|}
\hline & \multirow{2}{*}{$\frac{1 \text { st admission }}{20 \text {-Aug- } 80}$} & \multirow{2}{*}{$\frac{\text { 2nd admission }}{6 \cdot \mathrm{Jul}-87}$} & \multicolumn{2}{|c|}{ 3rd admission } & \multicolumn{2}{|c|}{ 8th admission } & \multicolumn{2}{|c|}{ 9th admission } \\
\hline & & & & 28-Mar-88 & 30-May-88 & 9 -Aug-90 & 22 -Oct-90 & 5 -Mar-91 & 30-Apr-91 \\
\hline T. Bil & $(\mathrm{mg} / \mathrm{d} l)$ & & 0.82 & 12.60 & 1.42 & 5.49 & 0.40 & 5.72 & 0.91 \\
\hline TTT & (U) & 10.0 & 36.6 & 35.6 & 9.3 & 35.5 & 14.5 & 19.3 & 23.4 \\
\hline ZTT & $(\mathrm{U})$ & 18.3 & 32.8 & 19.8 & 14.2 & 23.7 & 14.5 & 18.3 & 19.1 \\
\hline GOT & $(\mathrm{IU} / l)$ & 45 & 83 & 136 & 100 & 117 & 80 & 162 & 86 \\
\hline GPT & $(\mathrm{IU} / l)$ & 51 & 74 & 100 & 57 & 68 & 75 & 95 & 81 \\
\hline $\mathrm{LDH}$ & $(\mathrm{IU} / l)$ & 420 & 989 & 1,129 & 543 & & 453 & 587 & 408 \\
\hline ALP & $(\mathrm{IU} / l)$ & 134 & 784 & 924 & 564 & 336 & 229 & 393 & 484 \\
\hline$\gamma \cdot \mathrm{GTP}$ & $(\mathrm{IU} / l)$ & 264 & 428 & 542 & 185 & 82 & 165 & 103 & 121 \\
\hline T. chol & $(\mathrm{mg} / \mathrm{d} l)$ & 136 & 149 & 234 & 185 & 94 & 165 & 135 & 131 \\
\hline ICG $(R 15)$ & $(\%)$ & 6.2 & 15.0 & & & & & & \\
\hline $\mathrm{NH}_{3}$ & $i \mu \mathrm{g} \mathrm{d} l)$ & & & & & & & 123 & 39 \\
\hline $\mathrm{BCAA} / \mathrm{AAA}$ & & & & & & & & 1.2 & \\
\hline CRP & $(\mathrm{mg} / \mathrm{d} l)$ & & & 7.5 & & & & 14.7 & \\
\hline
\end{tabular}

b other laboratory data

\begin{tabular}{|c|c|c|c|c|c|}
\hline i) 1987.7 .6 & & $\operatorname{IgA}$ & $413 \mathrm{mg} / \mathrm{d} l$ & ANA & $\times 160$ \\
\hline RBC & $394 \times 10^{4} / \mathrm{mm}^{3}$ & Amylase & 80 somogyi $U$ & AMA & negative \\
\hline WBC & $4,200 \mathrm{~mm}^{3}$ & $\mathrm{ChE}$ & $0.70 \Delta \mathrm{pH}$ & thyroid test & negative \\
\hline Plts & $23 \times 10^{4} / \mathrm{mm}^{3}$ & $\mathrm{Fe}$ & $179 \mu \mathrm{g} / \mathrm{d} l$ & microsome test & negative \\
\hline HPT & $95 \%$ & $\mathrm{Cu}$ & $82 \mu \mathrm{g} / \mathrm{d} l$ & ii) 1991.3 .5 & \\
\hline $\mathrm{TP}$ & $8.2 \mathrm{~g} / \mathrm{d} l$ & ceruloplasmin & $27.0 \mathrm{mg} / \mathrm{d} l$ & $\mathrm{HCV} \mathrm{Ab}(\mathrm{Cl} 100-3)$ & - \\
\hline alb & $43.2 \%$ & AFP & $<5.0 \mathrm{ng} / \mathrm{m} l$ & & \\
\hline$\gamma \cdot g l$ & $34.8 \%$ & CEA & $1.8 \mathrm{ng} / \mathrm{ml}$ & & \\
\hline IgG & $3,722 \mathrm{mg} / \mathrm{d} l$ & $\mathrm{HBs} \mathrm{Ag} / \mathrm{Ab}$ & $-1+$ & & \\
\hline IgM & $240 \mathrm{mg} / \mathrm{d} l$ & $\mathrm{HBcAb}$ & + & & \\
\hline
\end{tabular}

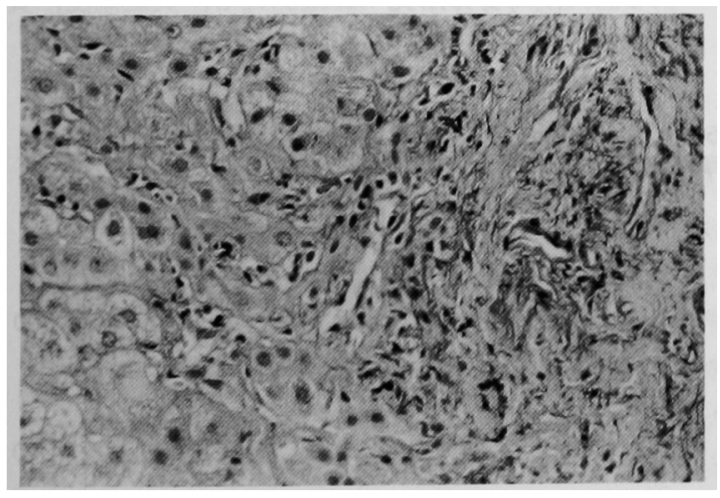

Fig. 1 Histological feature of the liver on the first admission. Periductal fibrosis, enlargement of portal area, and mild infiltration of inflammatory cells are seen $(\times 100)$.

1987年に住民検診にて再び肝機能異常を指摘され，精 查目的にて当科第 2 回入院.

第 2 回入院時現症：体格中等，篓養良，黄疸，負血

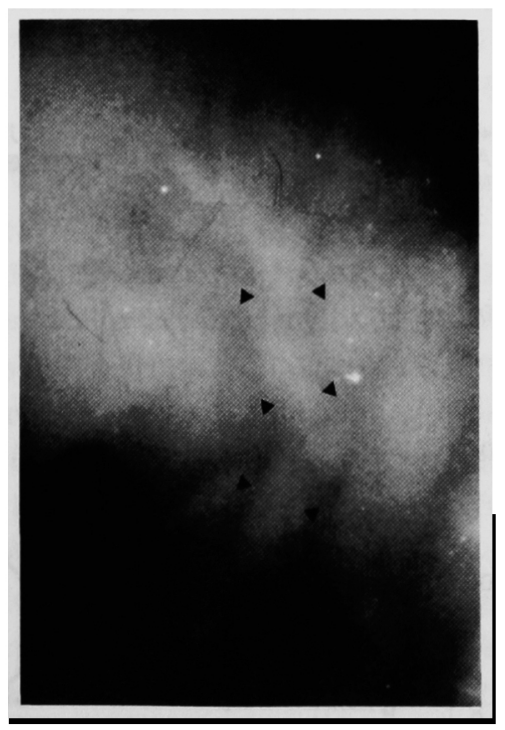

Fig. 2 Drip infusion cholangiography demonstrates intact common bile duct. Neither irregularity of duct wall nor stone was seen. 


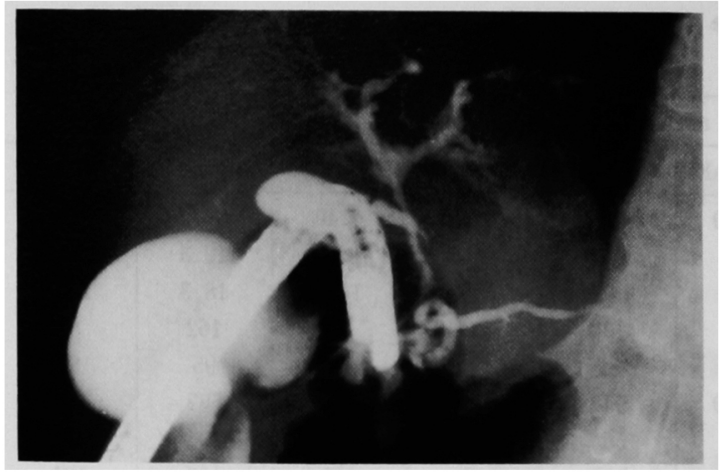

Fig. 3 ERCP on the second admission demonstrates rigidity and stenosis in intra and extrahepatic bile duct.

なし，肝脾触知せず。

第 2 回入院時検查成縝 Table：GOT，GPT ह \& 軽度の上昇を認め, 胆道系酵素は ALP $784 \mathrm{IU} / l, \gamma$ GTP 428IU/l と著增していた。 抗ミトコンドリア抗体 は陰性であり，免疫グロブリン分画では IgGが3,722 $\mathrm{mg} \mathrm{d} l$ と上昇していたが, IgM は正常範囲であった。

ERCP 所見 (Fig. 3)：肝内胆管, 総胆管の不整, 狭 窄像を認め，いわゆる beaded appearance を呈した。

便潜血陽性で施行した注腸透視 (Fig. 4)では上行結 腸ならびに横行結腸右半にてハウストラの消失, 小 ニッシェの多発を認め, 右半結腸型潰場性大腸炎 (UC) の所見をみた.PSC と診断し、胆道系醉素改善の目的

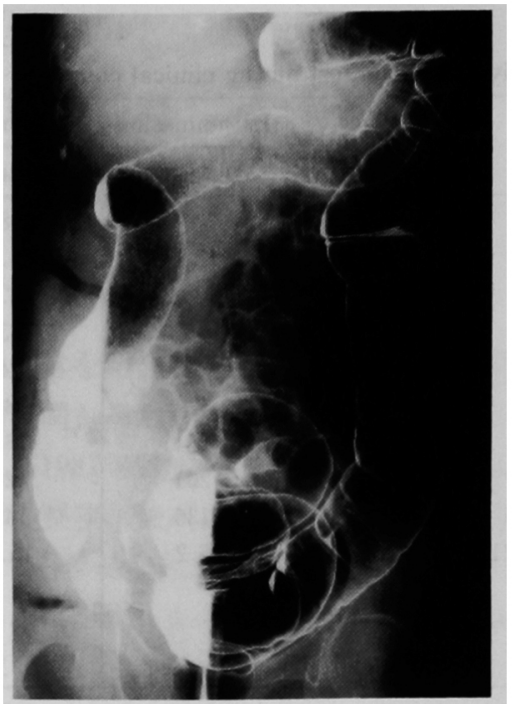

Fig. 4 Roentgenogram of the colon on the second admission shows disappearance of haustral markings, multiple small niches on the right hemicolon, although these findings were not observed on the first admission.

で, 同年 8 月24日より, predonisolone $30 \mathrm{mg} /$ 日の投与 を開始し，以後漸減した，ALP 值は10月20日には375 $\mathrm{IU} / l$ まで改善した。

1988年 3 月に初めて黄疸が出現し第 3 回入院.

第 3 回入院時身体所見：体温 $38.2^{\circ} \mathrm{C}$, 黄連高度, 貧

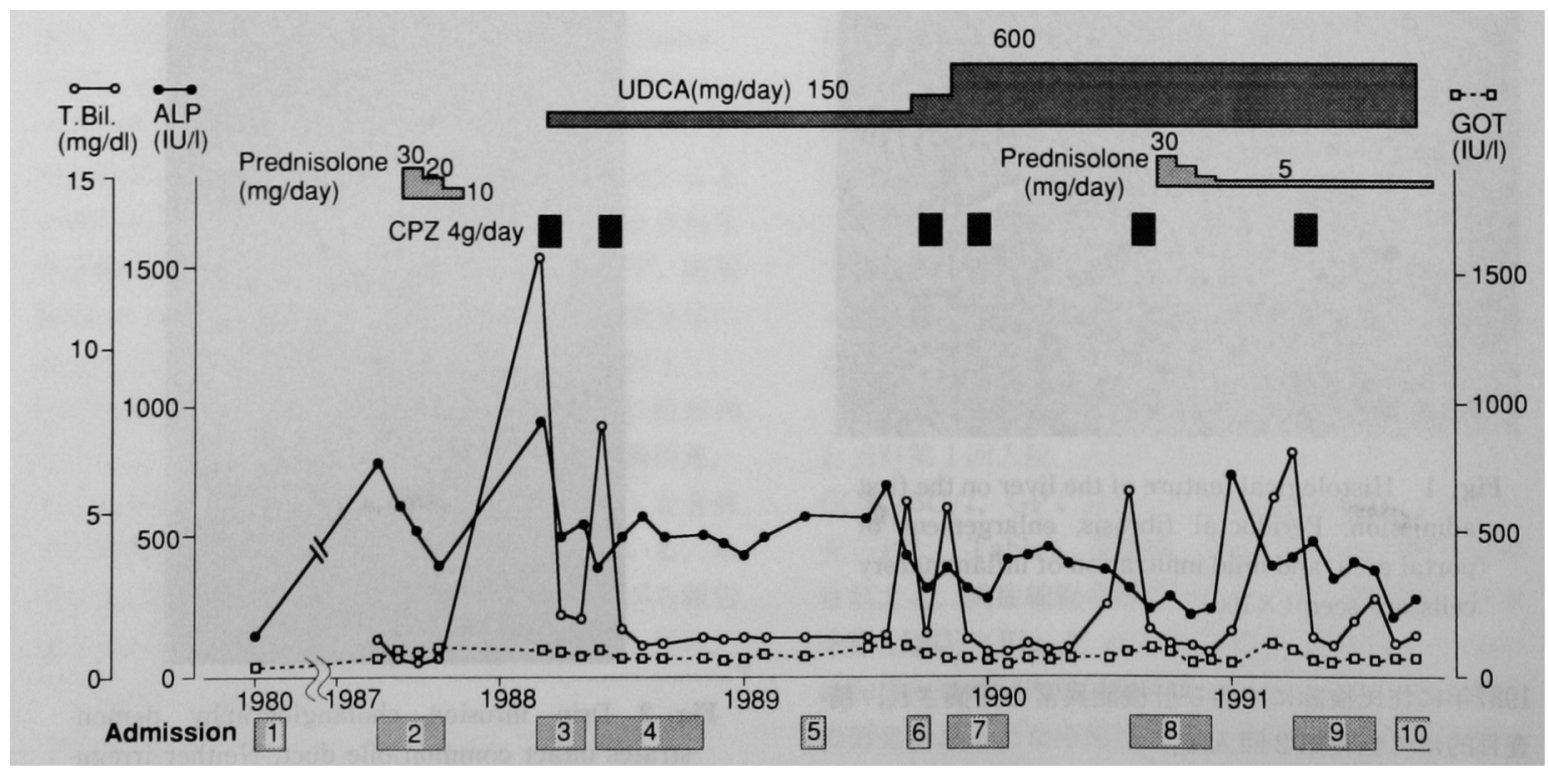

Fig. 5 Clinical course. 
血なし、肝脾触知せず, 浮腫なし.

第 3 回入院時検査成績 (Table): 白血球数6,700/ $\mathrm{mm}^{3}$ であり，CRP 7.5mg/d $l$ と強陽性を示した。総ビ リルビン $12.61 \mathrm{mg} / \mathrm{d} l$ と上昇し, GOT, GPT は中等度

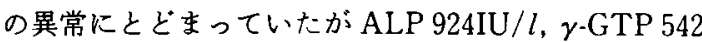
$\mathrm{IU} / l$ と著増を示していた。

腹部超音波検査：胆襄は腫大し，総胆管壁の硬化性 変化による閉塞性黄迫の所見であった。

入院後経過（Fig. 5)：発熱，炎症反応陽性などより 胆管炎による黄㡺発症と考之，安静，抗生剂(cefopera zone, $\mathrm{CPZ}$ )，肝庇護剤の投与などにて，翌日には解熱， 約 1 週間で黄㾝は消退した。利胆目的でゥルソデオキ シコール酸 (UDCA) $150 \mathrm{mg} /$ 日の経口投与を開始、一 旦は胆道采醉素値は改善したが(Table)，1988年 7 月， 再び胆管炎による黄迫にて入院した（第 4 回）。第 5 回 入院時の ERCP では, 胆管像は前回に比較して著変は みられなかった，以後UDCA 投与量を $600 \mathrm{mg} /$ 日まで 漸増したが，同年10月に全身倦䓌感を主訴に第 8 回入 院. 入院中 8 月上旬より再び黄疸出現し, CPZ $4 \mathrm{~g}$ の投 与を10日間行い黄逐は消失，その後 predonisolone 30 $\mathrm{mg} /$ 日より開始し，5mgまで漸減し継続投与してい る.

1991年 3 月全身浮腫を主訴に第 9 回入院.

第 9. 回入院時身体所見：意識：傾眠状態, 黄疸著明, 肝脾触知せす。四肢浮腫を認めた。

第 9 回入院時検査成績 (Table): 白血球数 $8,400 /$ $\mathrm{mm}^{3}, \mathrm{CRP} 14.7 \mathrm{mg} / \mathrm{d} l$ と炎症反応が高度であり, 総ビ リルビン $5.72 \mathrm{mg} / \mathrm{d} l$, GOT $162 \mathrm{IU} / l$, GPT $95 \mathrm{IU} / l$, ALP 393IU $/ l, \gamma$-GTP 397IU $/ l$ と上昇していた。血 中アンモ AAA 比は1.2と低下していた，CTにて肝は右葉萎縮， 左葉腫大の所見であり, 脾腫大も見られた，また上部 消化管内視鏡娭查にて食道静脈瘤を認め, 非代償性肝 硬変への進展か㠜われた。安静, $\mathrm{CPZ} 4 \mathrm{~g} /$ 日, 分岐鎖 アミノ酸輸液の連日投与により, 黄疸は軽减, 意識も 清明となり，アンモニフ値も正常化した。経過中に各 種自己抗体は陰性が持続し, HCV 抗体 $(\mathrm{C} 100-3)$ は陰 性であった。

\section{考案}

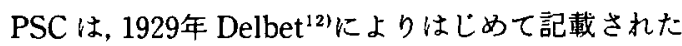
原因不明の，肝内および肝外胆管の炎症性硬化性変化 を来たし，最終的には肝硬変，肝不全へと進展する疾 患である，従来は閉塞性黄疸の進行した重症例の報告 が多く予後不良な疾患とされてきた ${ }^{13)}$ が，近年は
ERCPゃ PTCなどの診断技術の発達により，無症候 性 (asymptomatic PSC) として発見される例す増加 している3.14).このような症例のなかには, 数年から十 数年の経過を辿る例も報告されておう ${ }^{14)}$, 症候性例に 比して予後が良好であると考光られている。 また症候 性例であってむ長期間生存する例がみられなかには， 本例のように黄㾞の消長を示すものもあり, その臨床 経過は一様ではないと考えられる

PSC の診断基準については，報告者によって差異が あり，疾患概念自体にいまだ混乱がみられている。本 例においては、1) 胆石症や胆道系手術の既往がないこ と，2)最終的に胆管全域にわたって, 特有の壁不整像 がみられたこと、3）䅅過より悪性腫場は否定的である ことから，PSC との診断には問題がないと思われる。 また本例は初回入䟚時にPSCとの診断は得られてい ないが，その際の訮生検ではPSCに特有とされる炎症 細胞浸潤を伴った periductal fibrosisに矛盾しない所 見であり，DICにて総胆管像に異常はみられていない ことより,無症候性肝内胆管型 PSC として発見された ものと考えられる。

本例に招いては，11年の経過中, 胆道系の慢性炎症 ならびにその急性増悪と考えられる血清 ALP， $\gamma$ GTP 値の上昇や, 黄疸の出現がみられ胆管病変は訮内 胆管から肝外胆管の順で進展していた，PSCにおける 胆管病変がどのうな進展経過をとるかについては， 一致した見解が得られていないが, 従来はPSCの主病 変は肝外胆管の肥厚や硬化性変化であり, 肝内は胆汁 うっ滞とこれに基づく二次性変化であると考えられて いた ${ }^{16)}$.しかし1966年の Hellstrom ら ${ }^{171} に$ 始まり訮内 型硬化性胆管炎の報告も少なくなく，Ludwig $5^{6 !}$, Wiesner ら》はPSCの肝生検における，とくに PBC との鑑別に重点をおいた娭討にて, 線維性閉塞性胆管 炎（fibro-obliterative cholangitis）が特徽的であり， Bhathal ら ${ }^{18)}$ が肝内のみにこのような所見を認めた例 を Primary intrahepatic obliterating cholangitis $と$ 称して以来, 肝内と肝外の病変は同一の疾患単位とし て考えるのが一般的になっている.さらに Blackstone $ら^{19)}$, Wee $ら^{201}$ はC に合併した肝病変として肝生検 にて認められた pericholangitisが肝外胆管にまで進 展した例を報告しておりこのよらな点を踏ま省て LaRusso ら"は肝内胆管型 PSC が本疾患の初期像を 示しているのではないかと考察している. 本邦におい ても吉田ら ${ }^{5}$ が, UC 合併の無症候性 PSCにおいて, 肝 内胆管から肝外胆管への病変の進展を認めたといら 1 
$94: 676$

例を報告している。

前述の吉田らの報告例洤経過が無症候性に経過 しているが，本例においては，胆管病変が肝外胆管に も進展した以後に, 胆管资を発症し, 黄㾝が出現した. 従って本例における黄㡺の原因は, PBCの場合とは異 なり，肝外胆管のような大きな胆管レベルでの障害に 伴う胆管炎や胆道閉塞であると考えられる。この点に ついて,さらには肝外胆管に病変をもたない肝内型 PSCの多くが無症候性であることも考え合わせ興味 深い.

PSC と炎症性腸疾患との合併については，欧米では 50〜 70\%程度の高率に報告されており，中でもUCの 合併が殆どである. 本邦における合併率は, 吉田ら よる91例の集計では15.3\%であり，合併例はすべて肝 内胆管の病変を有する例であった，本例では，初回入 院時, 肝内胆管のみに病変が認められた段階での注腸 透視にては異常なく, 胆管病変が肝外にむ広がった後 に，注腸逶視にてハウストラの消失などUCに特有と される所見が出現しており、肝内PSCがUCに先行し ていたものと考竞られたかかて PSCの病因の一つと して，門脈菌血説が挙げられていたが，これはUC患 者に門脈菌血症が多く,かつPSCの合併が多いこ上に 基ついている. またこのことより UCはPSCに先立っ て発症するものと考えられていたが, Steckman ら¹ は, 肝生検上の変化が UC 発症に先立ってみられ，後 に ERCPにてPSC と診断した 4 例を報告している。 本例では, 訮内 PSC が先行し, UC, 訮内外型 PSC の 発症が後に続くといら進展の順序が確認された。

PSCの治療については，未だ特異的なるのは開発さ れていない，副腎皮質ステロイド単独投与，または cholchicine, azathioprine との併用㞠法により肝機能 成績の改善がみられたとする報告”があるが, casecontrol study がなされておらず，その有効性について は確認されていない.近年, UDCAのPBCに対する有 奻性が示され221，同じように胆汁うっ滞の病態を示す PSCに対してUDCAの投与を試みた成績も報告され ている ${ }^{8,9)}$. Chazouilleres ら ${ }^{8)} 15$ 例の PSC 患者に対 しUDCA の投与によりALP， $\gamma$-GTP 値の改善が見ら れたとしており，林らのの報告例は血夜生化学的所見 は改善したが胆管像には変化がなかった，本例に対す るUDCA 投与は，当初は150mg/日の少量投与では あったが, 胆管炎の発症を阻止しえず, $600 \mathrm{mg} /$ 日への 増量および副腎皮質ステロイドの追加後す黄疸や高ア ンモニア血症, 腹水が出現し, ERCPによる胆管像に
34 巻 8 号 (1993)

あ変化がなかった。このことよりUDCAの持つ利胆, 胆汁酸組成の変化に上るChenodeoxycholic acid (CDCA)の毒性减弱といった作用は, PBCの病変の主 座である肝内の小胆管に及ぼされ，胆道系醭素の改善 をもたらすか，本例での黄疸の原因となる大きな胆管 の炎症性狭窄性変化に対しては何ら影響を及ぼしてい ないことが推測される。

以上のこ゚とく本例は, 病因, 臨床像に不明の点が多 いPSCの病態を考点るらえにおいて、多くの示唆を与 党るのと考えられ、ここに報告した。

\section{結語}

無症候性肝内型 PSC として発見され，以後11年間に わたって, 症候性への進展を観察しえたUC 合併 PSC の 1 例を報告した。 その臨床経過において, 胆管病変 は肝内胆管から肝外胆管へ進展していた。 た肝内 PSCかＵCの発症に先行していた.ささらにUDCA, 副 腎皮質ステロイド投与は胆道系酵素の上昇を改善した が, 黄疸の出現や肝病変の進展は抑制しえなかった。

\section{女 献}

1) LaRusso NF, Wiesner RH, Ludwig J, et al: Primary sclerosing cholangitis. N Engl J Med 310:899-903, 1984

2) Chapman RWG: Primary sclerosing cholangitis. J Hepatology 1 : 179-186, 1985

3) Chapman RWG, Marborgh BA, Rhodes JM, et al: Primary sclerosing cholangitis: A review of its clinical features, cholangiography and hepatic histology. Gut $21: 870-877,1980$

4) 平井信行, 加登康洋, 松下栄紀, 他：長期間経過を 観察した原発性硬化性胆管资の1例. 肝荿 28 : $606-613,1986$

5) 吉田行哉, 竹内和男, 中島正男, 他：潰汮性大腸炎 と合併し肝内胆管から肝外胆管へ病变の進展を認 めた無症候性原発性硬化性胆管炎の 1 症例. 日消 誌 $84: 2597-2602,1987$

6) Ludwig J, Czaja AJ, Dickson ER, et al : Manifestations of non-suppurative cholangitis in chronic hepatobiliary diseases: Morphologic spectrum, clinical correlations and terminology. Liver 4 : 105-116, 1984

7) LaRusso NF, Wiesner RH, Ludwig J, et al: Prospective trial of penicillamine in primary sclerosing cholangitis. Gastroenterology 95: 1036-1042, 1988

8. Chazouilleres O. Poupon R, Capron JP, et al : 
Ursodeoxycholic acid for primary sclerosing cholangitis. J Hepatol 11 : 120-123, 1990

9）林 久男，领口知之，一宮 洋，他：ウルッデオキ シコール酸療法を施行した無症候性原発性硬化性 胆管炎の 1 例。日内会誌 $78: 89-90,1989$

10) Lindor $\mathrm{KD}$, Wiesner $\mathrm{RH}$, Colwell LJ, et al : The combination of prednisone and colchicine in patients with primary sclerosing cholangitis. Am J Gastroenterol 85 : 57-61, 1991

11) Wiesner RH, LaRusso NF : Clinicopathologic features of the syndrome of primary sclerosing cholangitis. Gastroenterology 79: 200-206, 1980

12) Delbet MP: Retrecissement du choledoque, Cholechysto-Duodenostomie. Bull Men Soc Nat Chir $50: 1144-1146,1924$

13）伊藤信康, 大石明徳, 為田斳彦, 他：原発性硬化性 胆管炎の 2 剖検例と本邦報告例51例の臨床的検 討. 肝㬸 23:1184-1192, 1982

14) Chapmann RWG, Borroughs AK, Bars NM, et al: Long-standing asymptomatic primary sclerosing cholangitis, report of three cases. Dig Dis Sci $26: 778-782,1981$

15) Thompson HH, Pitt HA, Tompkins RK, et al: Primary sclerosing cholangitis, a heterogenous disease. Ann Surg 196: 127-136, 1982

16) Holubitsky IB, McKenzie AD: Primary sclerosing cholangitis of the extrahepatic bile ducts. Can J Surg 7 : 277-283, 1964

17) Hellstrom HR, Perez-Stable EC: Retroperitoneal fibrosis with disseminated vasculitis and intrahepatic sclerosing cholangitis. Am J Med $40: 184-187,1966$

18) Bhathal PS, Powell LW: Primary intrahe. patic obliterating cholangitis: A possible variant of "sclerosing cholangitis". Gut 10:886 $-893,1969$

19) Blackstone MO, Nemchausky BA : Cholangiographic abnormalities in ulcerative colitis as sociated pericholangitis which resemble scleros ing cholangitis. Digestive Diseases $23: 579-585$, 1978

20) Wee A, Ludwig J: Pericholangitis in chronic ulcerative colitis: Primary sclerosing cholangitis of the small bile ducts? Ann Int Med 102: 581-587, 1985

21) Steckman M, Drossman DA, Lesesne HR: Hepatobiliary disease that precedes ulcerative colitis. J Clin Gastroenterol 6 : 425-428, 1984

22) Poupon R, Chreitien $Y$, Poupon RE, et al : Is ursodeoxycholic acid (UDCA) an effective treatment for primary biliary cirrhosis? Lancet $1: 834-836,1987$ 


\title{
A long-term follow-up case of primary sclerosing cholangitis showing a progression from asymptomatic to symptomatic state
}

\author{
Osamu Yamakawa, Yasuhiro TAKEMORI, Yatsugi NodA* and Goroku OHTA**
}

In 1980, a 64-year-old female was first admitted to our hospital after pointing out of liver injury in a mass survey. A mild elevation of serum ductal enzymes were observed on the laboratory data. And histological findings of the liver revealed fibrous expansion and inflammatoric change of portal area. However, the common bile duct appeared to be normal on drip infusion cholangiography and normal colonogram was obtained. After 7 years she admitted for liver examination again. Ductal enzymes had remarkably elevated, and ERCP demonstrated typical beaded appearance in the whole biliary tree. In addition, barium enema examination showed a loss of haustral marking and the presence of small ulcers of the colon. In the present case, the lesion extended from the intrahepatic bile duct to the extrahepatic bile duct, and intrahepatic PSC preceded UC. In 1988, she first showed jaundice and then ursodeoxycholic acid (UDCA) was administered. Although UDCA improved the elevation of ductal enzymes, recurrent jaundice has been sustained. No significant change was shown in cholangiogram by the examination of follow-up ERCP. Now she is suffering from decompensated liver cirrhosis due to PSC.

\footnotetext{
* Department of Internal Medicine, Toyama Rosai Hospital (Uozu, Toyama)

** Department of Pathology, Toyama Rosai Hospital (Uozu, Toyama)
} 